\title{
CONVERSION AND REUSE OF THE FORMER MILITARY TRAINING AREA OF RALSKO
}

\begin{abstract}
V. Poštolk a: Conversion and Reuse of the Former Military Training Area of Ralsko. - Geografie - Sborník ČGS, 103, 3, pp. 285 - 299 (1998). - Ralsko area on 250 sqkm was used as one of the largest military areas in the years 1945 - 1991 (after 1968 the largest Soviet Army Base in the country). At present it is the largest area in the country in need of conversion/reuse. The area is very interesting and unique in terms of nature, landscape, water supply and tourism. Some reuse and future use projects and ideas are being prepared and developed. The paper contains sections dealing with Site identification and characterization, History of military use, Ongoing conversion and reuse process, Planning for future use, Available and useable financial sources, Goals, expectations and visions, Projects and priorities, NATO CCMS pilot study, Recommendations and Conclusions.

KEY WORDS: former military lands - Ralsko area - conversion and reuse process financial sources - NATO CCMS Pilot study.
\end{abstract}

\section{Introduction, position and basic data}

The former military training area (further abbr. as MTA) of Ralsko (or formerly also Mimoň) had $250 \mathrm{sqkm}$ and was until recently the second largest MTA in the Czech Republic. It was established in 1950 and used by the Soviet Army from 1968 to 1991. After the Soviet Army's withdrawal it was decided to discontinue its military use. Since the beginning of 1992 it has been the largest former MTA in the country looking for reuse and conversion.

The Ralsko area lies about $75 \mathrm{~km}$ north of Prague and only $20 \mathrm{~km}$ from the joint Czech - German - Polish border. The largest towns in the nearest surroundings are Česká Lípa (40 thsds inh.), Mladá Boleslav (45 thsds inh.) and Liberec (100 thsds inh.). Among smaller towns bordered directly by the former MTA , Mimoň ( 7 thsds inh.), Doksy ( 5 thsds inh.) and Stráž pod Ralskem (4 thsds inh.) are the most important.

The Ralsko area is first of all an unique area because of its natural heritage. Almost $90 \%$ of its total area has remained untouched - according to some experts - by direct human impact in the last 50 years. It is very rare in Central Europe to find such a large and continuous area kept in substance only in natural development. From this point of view the Ralsko area may be considered one of the most interesting and valuable areas in Central Europe. Ralsko is for these reasons one of two areas in the Czech Republic, which have been declared "biogenetic reserves" within the European network (EECONET). 


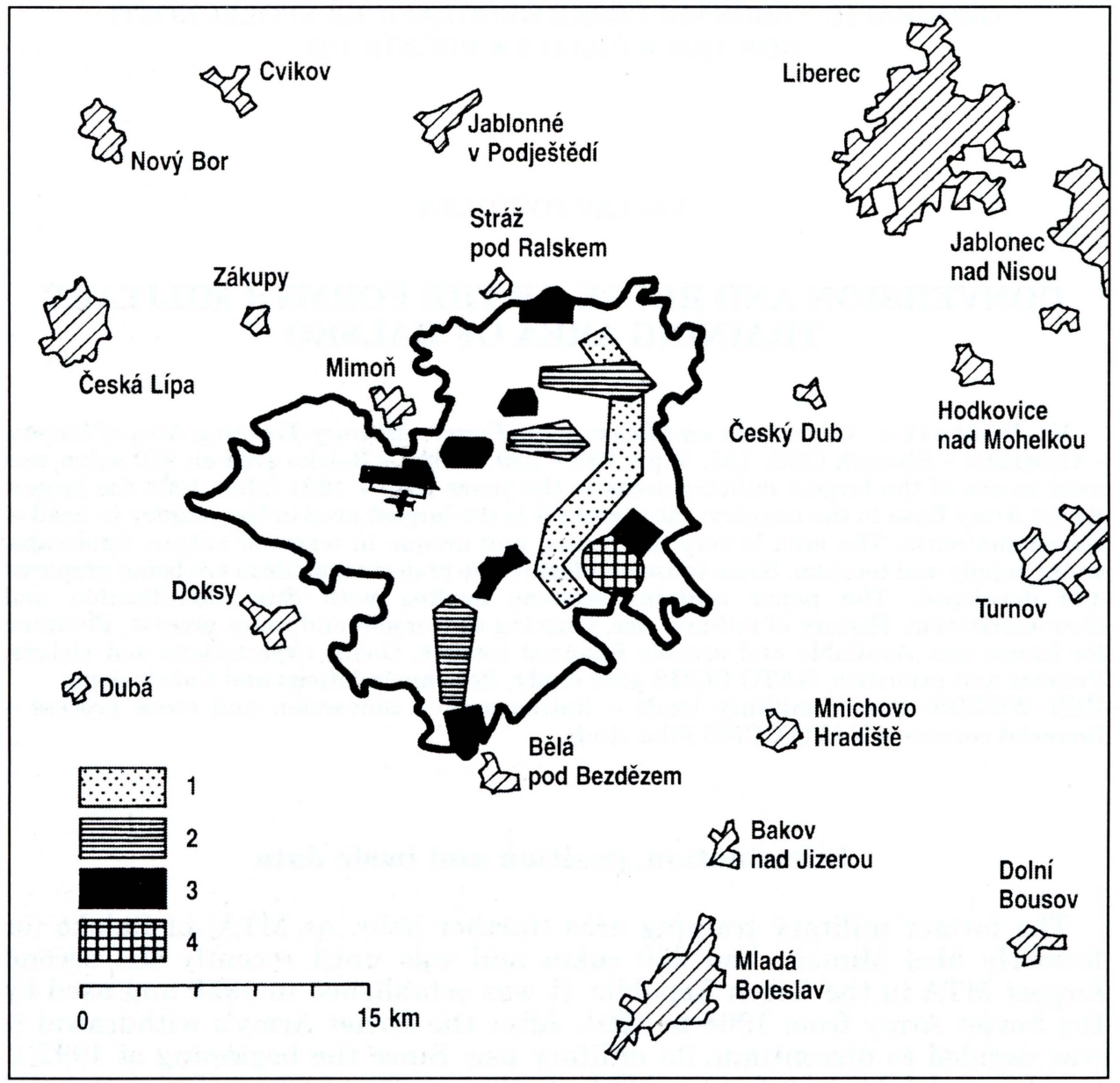

Fig. 1 - Borders and affected sites of the former military training area of Ralsko. 1 movement of land forces vehicles, 2 - areas used for shooting, 3 - barracks building, 4 aeroplane firing range.

\section{Site identification and characterization}

Ralsko was the largest military training area $(250 \mathrm{sqkm})$ used by the Soviet Army in the Czech Republic. The Soviets abandoned the area in 1991 and the majority of buildings and facilities used by the army have remained unoccupied. The former military base which constitutes approx. $24 \%$ of the total Ralsko area has also been almost totally abandoned. There is also a former military airfield at Hradčany which is in particular suitable for upgrade and reuse.

More than $72 \%$ of the area is forest. Ralsko also lies within one of the largest underground water aquifers in the country. The area and its all surroundings are considered to be a very valuable and attractive region for use as a nature preserve and as a center for cultural heritage and tourism. 


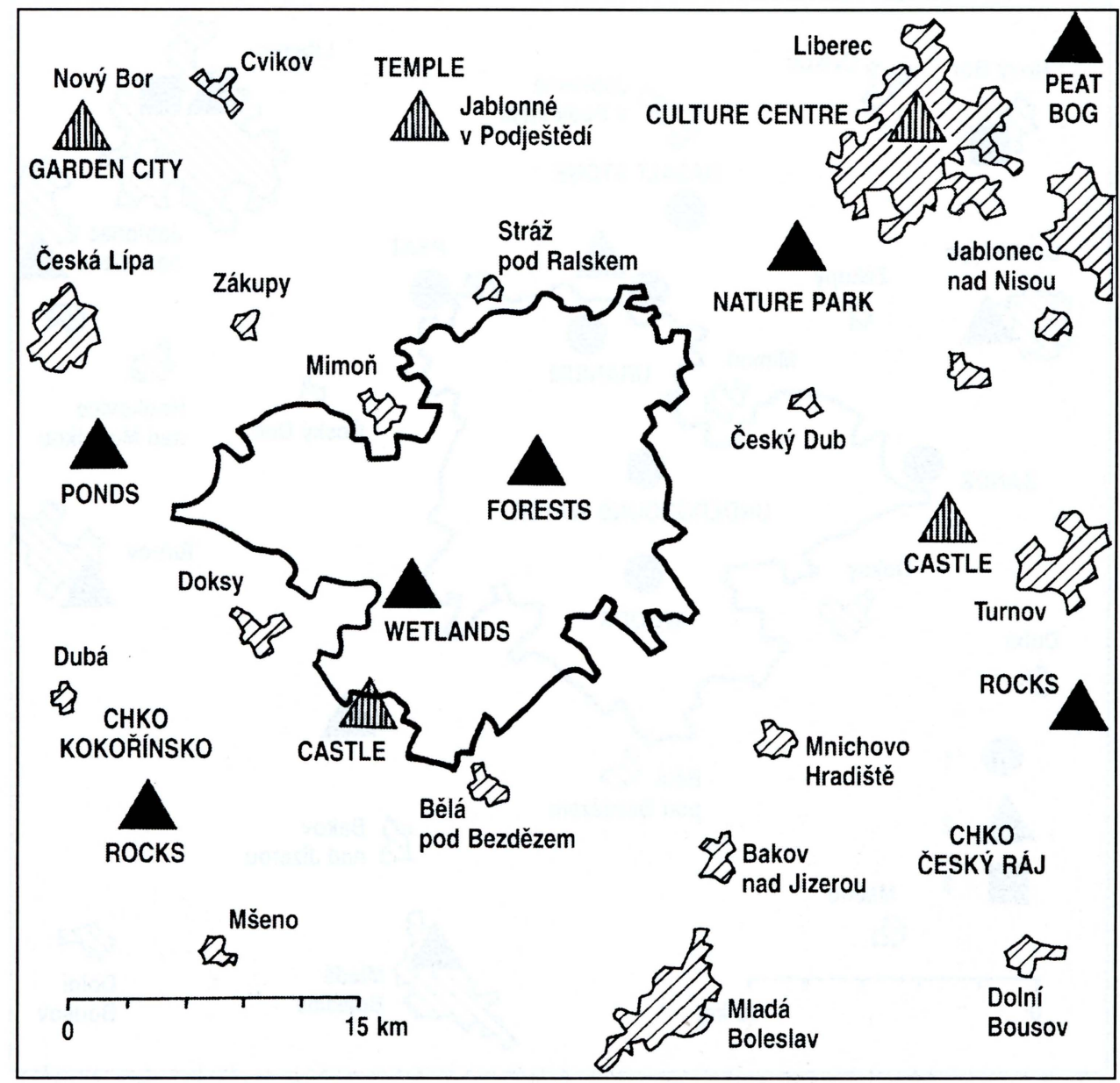

Fig. 2 - Conversion/reuse of the former military training area Ralsko (Czechia) - natural and cultural heritage.

Ralsko - Hradčany offers great promise as a vacation area. It should be quite attractive to Western Europeans due to its location, only $75 \mathrm{~km}$ north of Prague and a short $20 \mathrm{~km}$ from the German border.

The PRIVUM Agency was formed in 1994 by the Czech Government to organize and promote privatization and the transfer of ownership. In a short time all the lands and buildings were identified (and registered) from which 651 buildings and 5,401 hectares are now designated for privatization. The regional masterplan for the Ralsko area was approved in 1994 by the Czech Government. The set of local land-use plans serves as a convenient base for the promotion and coordination of economic, social, cultural and natural developments.

Three major business enterprises exist in this area: a central coal - fired heating plant (with surplus capacity), a plant making pet food, and a forested area which includes a tree nursery, sawmill and hunting preserve. The Czech Army undertook a vital pyrotechnical investigation and is rapidly cleaning up areas threatened by UNOs which had been firing ranges. The Czech Ministry 


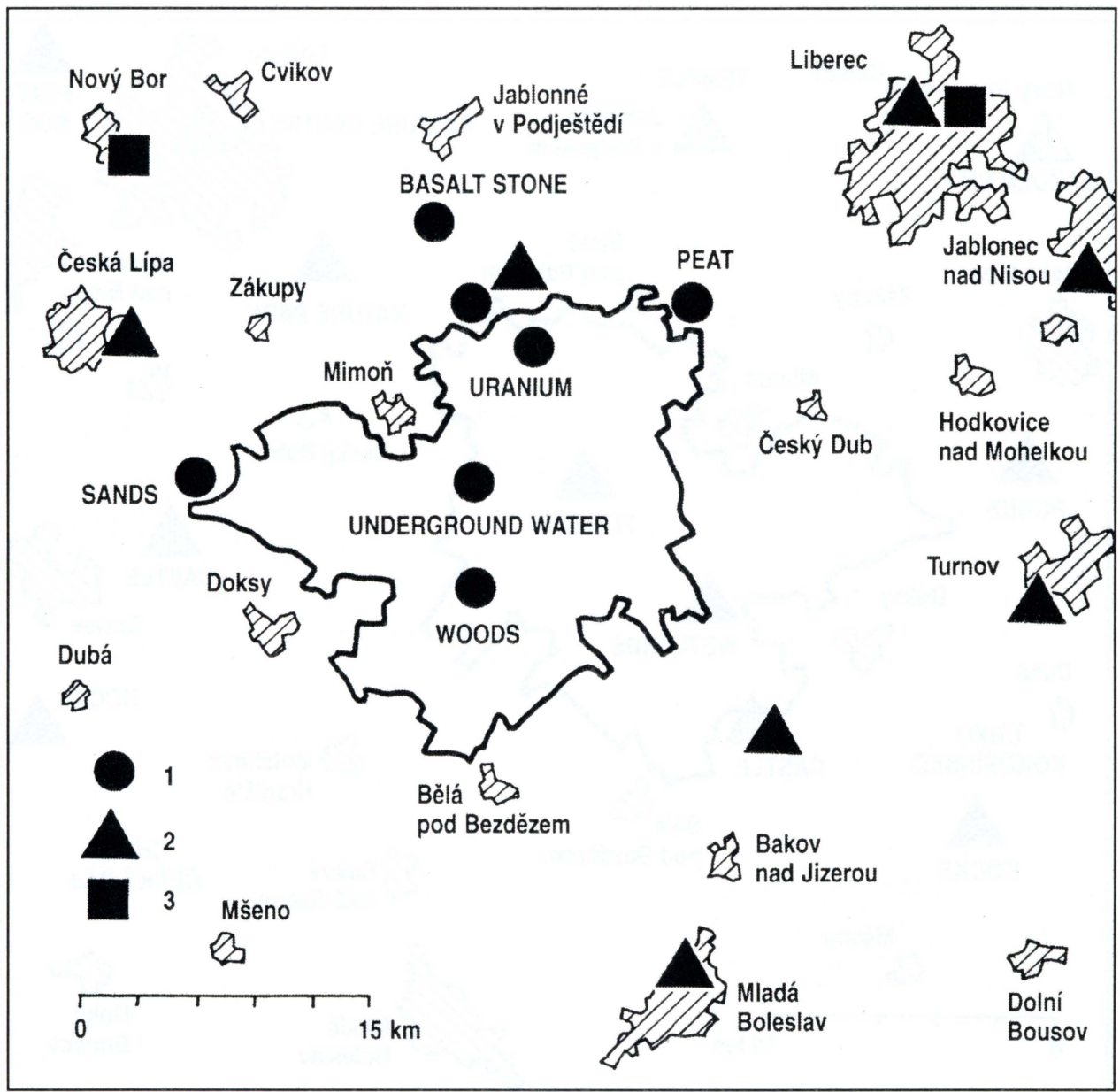

Fig. 3 - Conversion/reuse of the former military training area Ralsko (Czechia) - raw materials and industry. 1 - raw materials, 2 - heavy industry, 3 - light industry.

of the Environment is conducting remediation and decontamination on an impressive scale.

The major part of the former military base belongs nowadays to the Ralsko Municipality with only 750 permanent inhabitants at present (1998) living on $170 \mathrm{sqkm}$. There were more than 2,000 abandoned flats which are now being partly modernized and re-rented.

\section{History of military use}

Before 1945 more than 7 thsds. inhabitants, mostly of German nationality and German speaking, had been living in this area. Settlement of that area was spread over 20 mostly agricultural villages and the small town of Kuřivody (Huehnerwasser). Other larger settlements were Svébořice (Schwabitz) and Hradčany (Kummer), at that time a popular summer area. 


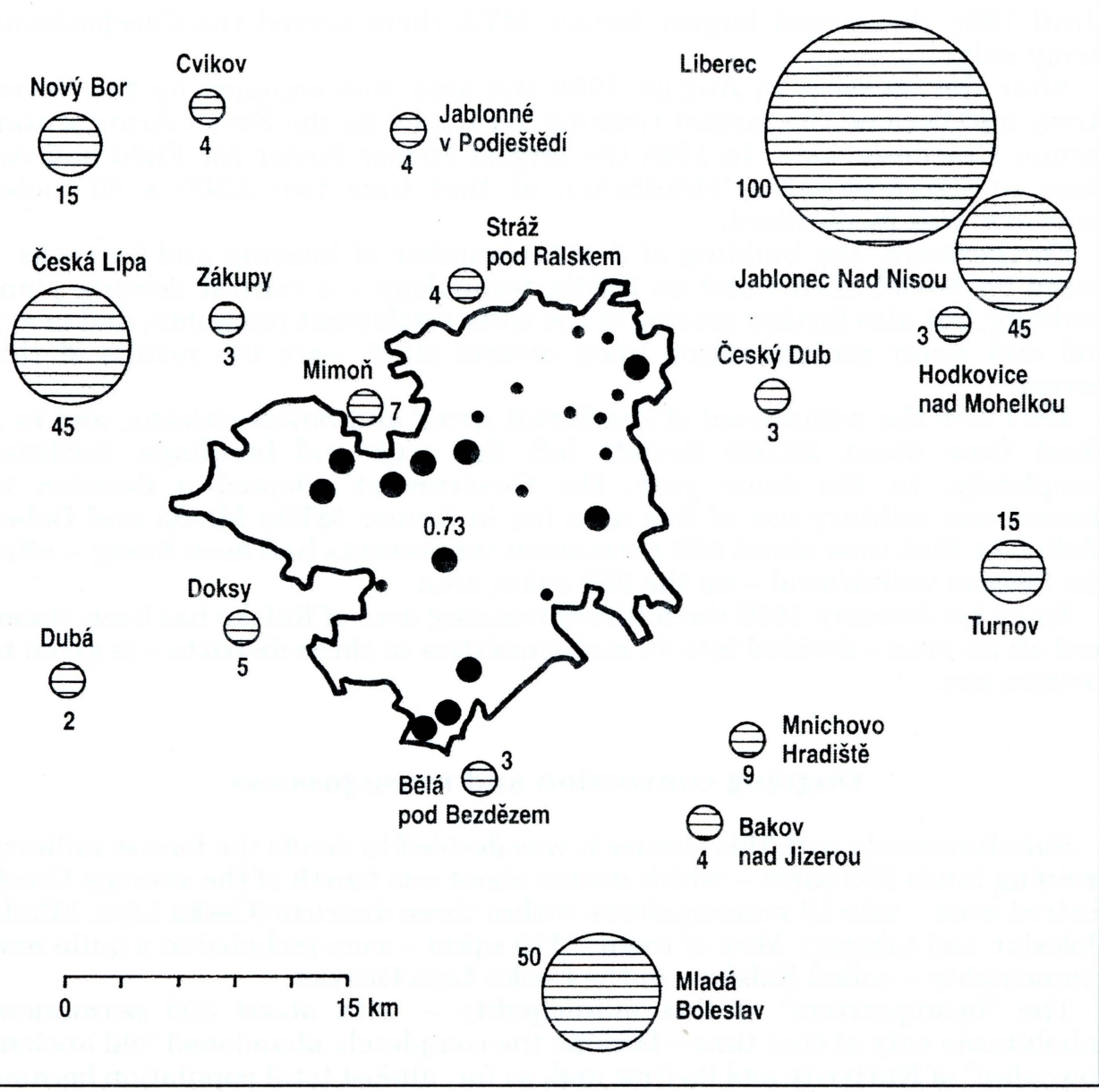

Fig. 4 - Conversion/reuse of the former military training area Ralsko (Czechia) - population and settlements. The size of the circles is in direct proportion to population number (1996) in thousands. Filled in mark $=$ deserted, completely liquidated settlements.

By the end of World War Two in 1945 the Germans had built the military air base near Hradčany (Kummer), which probably was envisaged as having a significant future role in the region.

After the transfer of German population at the time of the ongoing new settlement in 1946, the first considerations and proposals to establish a military training area (or as it was called at that time "the military campus of Bezděz") in this region were already being made by the Czechoslovak Goverment. The beginning of resettlement and the increasingly economic and social problems already affecting the new and mostly Czech population were bound up with these proposals.

In 1950 "the military training area" was declared and delimitated by the Czechoslovak Government on $250 \mathrm{sqkm}$, where about 3,5 thsds inhabitants had been living at that time.

Up to the end of 1952, in the three following years, more than 3 thsds inhabitants were resettled from 15 villages designated fully for military use. 
Until 1968 the second largest former MTA there served the Czechoslovak Army only.

After the invasion in August 1968 the area was occupied by the Soviet Army and became the largest training area used by the Soviet Army within former Czechoslovakia. In 1988 the largest former Soviet Air Field and Air Base in Czechoslovakia (Hradčany), at that time two 2,500 x 80 meter runways, was modernised.

Furthermore, the building of a great number of housing and barracks based on Soviet norms and on Soviet technology - a central heating plant building, but also further ceasing of the older settlement remnants, and heavy soil and water contamination upon several sites, were the results of this period.

1991 saw the withdrawal of the Soviet Army and Soviet citizens, and in a short time about 20,000 Soviets left the area and buildings, facilities completely. In the same year, the Government adopted a decision to discontinue military use of this area (as in former MTAs Mladá and Dobrá Voda). At that time about 500 permanent inhabitants had been living - after the Soviets withdrawal - on the $250 \mathrm{sqkm}$ area.

Since 1st January 1992 the military training area of Ralsko has been closed and all its area - divided into 13 municipalities in three districts - is given to civilian use.

\section{Ongoing conversion and reuse process}

Simultaneously with this closure it was decided to divide the former military training lands $250 \mathrm{sqkm}$ - which means about one fourth of the average Czech district area - into 13 municipalities within three districts (Česká Lípa, Mladá Boleslav and Liberec). Most of them - $170 \mathrm{sqkm}$ - were included in a quite new municipality - called Ralsko - in the Česká Lípa District.

The "headquarters" of this municipality - with about 500 permanent inhabitants only at that time - became the completely abandoned "old ancient township" of Kuřivody and its first and, so far, almost total population became the so-called Volhynian Czechs. At present the largest group of those is "settled" here in Kurrivody. There are about 190 of them, who had been living in the part of Ukraine affected by the Chernobyl disaster, and who between 1991 and 1993 decided to go back to the country of their ancestors.

Extensive pyrotechnical and hydrogeological investigations started in1992, followed by extensive cleaning up covered by the state budget

In 1993 the Czech Goverment adopted regulations relating to the conversion and reuse of former military lands including privatization procedures. Following this decision, the PRIVUM (Privatization of Military Lands of Mladá and Ralsko) State Agency based in the town of Lysá nad Labem (near the former Mladá MTA, where the Headquarters of the Central Group of Soviet Army was situated) was established by the Czech Government in 1994, in order to organize and promote privatization of the state property within two closed former military training areas - Mladá (also Milovice) and Ralsko (also Mimoň).

In 1995 all buildings and lands were identified by the PRIVUM Agency based on Arc Info GIS (Geographic Information System). In total 1,700 flats and 1,200 other buildings were identified within the Ralsko area, mostly at the Hradčany Air Base. 


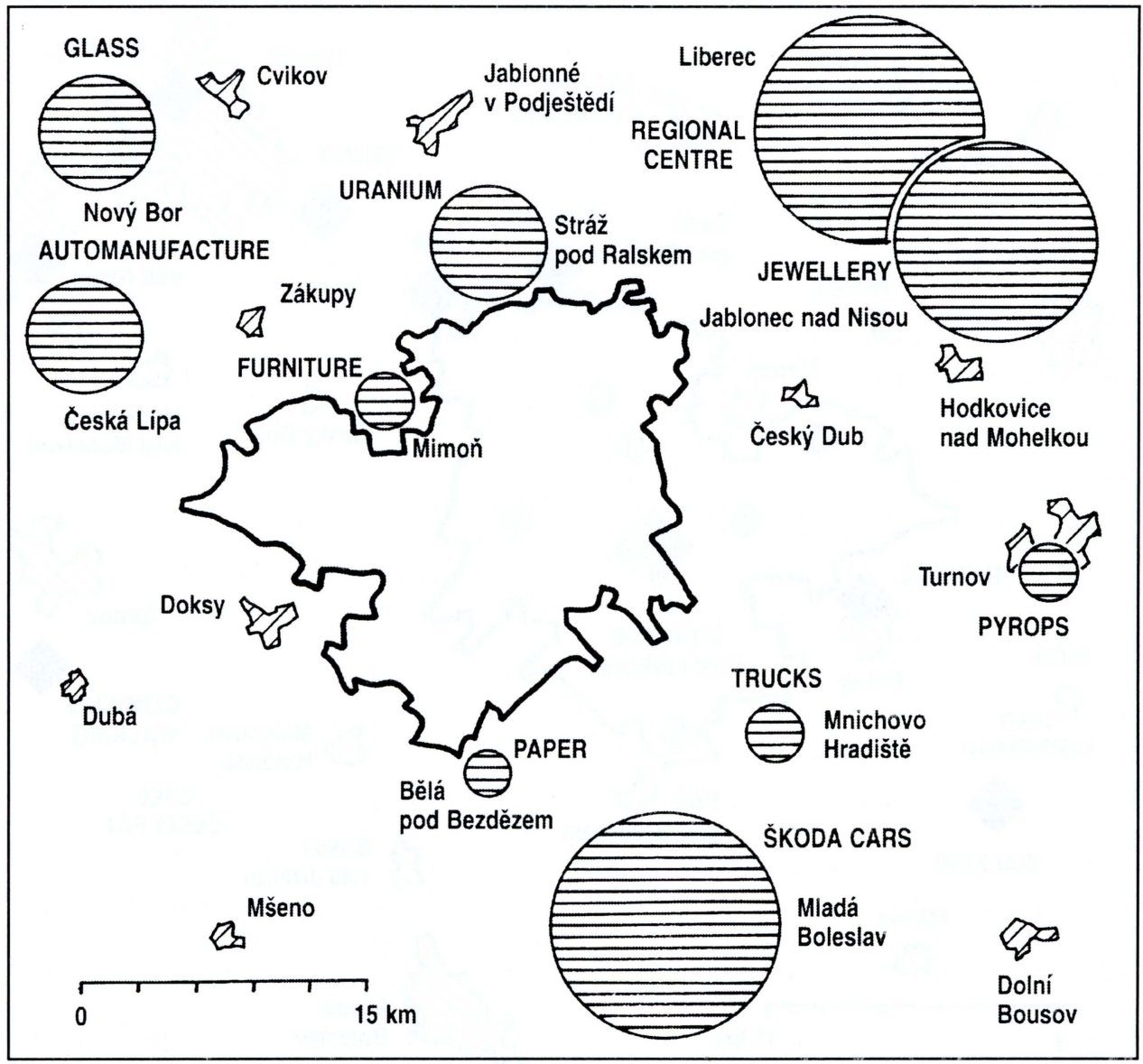

Fig. 5 - Conversion/reuse of the former military training area Ralsko (Czechia) - economic power. The size of the circles expresses the economic power of the surrounding centres.

In 1996 - 1998 about 360 (30\%) buildings and 780 (45\%) flats were transfered from the state to municipalities and other new owners, and technical networks have been transfered to new owners too.

In 1996 the town of Mimon - with state financial contributions and a grant - began the upgrading and modernisation of the abandoned block of flats located at the Hradčany Air Base. In 1997 the newly fitted and upgraded flats were already occupied.

In 1997 the Czech Goverment approved the use of financial means raised from the sale of state property for technical infrastructure fitting and building.

The Ceská Lípa District Museum organized an interesting exhibition called "Military Training Area of Ralsko - Yesterday, Today and Tomorrow" in 1995. This exhibition resulted also in a special handbook issued in 1997, which contains mainly reviews of and research into the natural values of these "forgotten lands and sites".

In 1997 the "Association of Municipalities concerning Conversion and Reuse of the former Ralsko MTA" launched its activities. Its members 


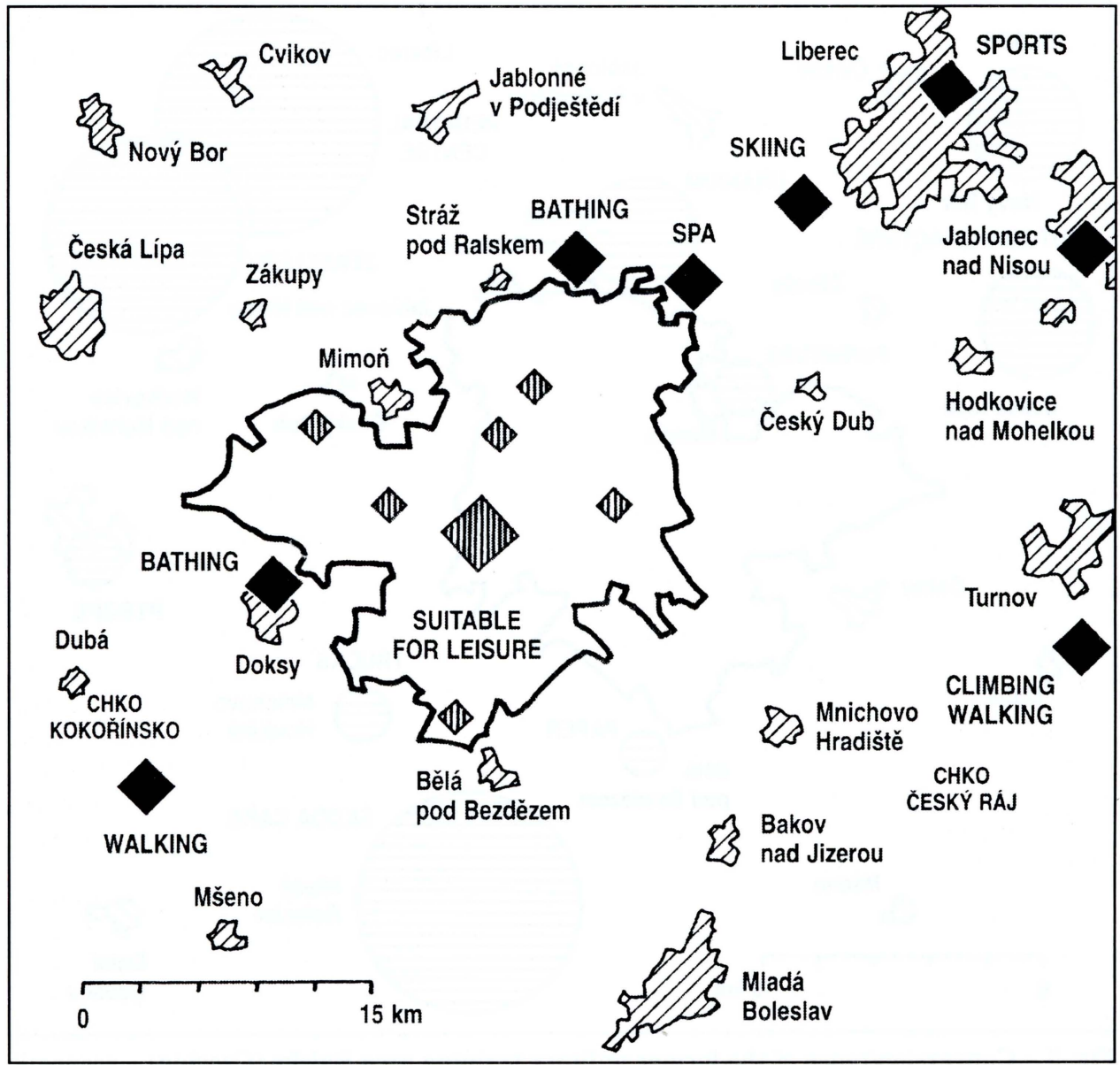

Fig. 6 - Conversion/reuse of the former military training area Ralsko (Czechia) - tourism, recreation and leisure.

includes the municipalities of Ralsko, Noviny pod Ralskem, Hamr na Jezeře, Osečná, and the towns of Mimoň, Stráž pod Ralksem, Doksy, Bělá pod Bezdězem and Zákupy, and also the district authorities of Česká Lípa, Mladá Boleslav and Liberec.

\section{Planning for future use of lands and resources}

Early in 1993 the first, ambitious project (vision) for future use called "Ralsko - Free Zone of North Bohemia" was prepared and contains a huge volume of information and data about this at that time still "forgotten and unknown" area.

In 1994 the Regional Masterplan for the Ralsko Area (maps in the scale of $1: 25,000$ ) was created and approved by the Czech Government. The approved proposal contains proposed and delimited preferable reuse activities (sites). 
In 1995 the "Ralsko Region - Needs Assessment for Economic Development" done by the U.S. Foundation for a Civil Society analysed the position, structure and development chances from and for a foreign investment prospective.

In 1995 several studies and visions concerning the "Breeding Station for Endangered Animal Species - Svébořice" were elaborated, in which the Zoological Garden of Liberec has been mostly and mainly involved. This intention was presented firstly in 1995 at the NATO Advanced Workshop held in Liberec, and after that it became also part of a developing presentation of conversion/resuse options in the NATO CCMS Reuse Pilot Study framework.

Among other planning tools the "Strategic and Development Study" is worth mentioning. It was prepared in 1996 by the joint cooperation of Universities teachers and students involving on one hand architecture, landuse and on the other hand economic subjects. In this study five different ways (options) for future use are proposed and assessed. One of them is designated "return to military use".

In 1997 "Ralsko Area and its Use for Leisure and Tourism Activities - A Study" for the needs of the Ministry of Regional Development was elaborated, confirming and pointing out various and hopeful options, and also demanding increased state or foreign financial support for tourism promotion.

In the course of 1996 - 1998 a wide set of local land - use plans and projects (in the scale 1:5,000 or 1:2,000) were completed or drafted to cover all sites developed (designated) for future use. At present there are available land-use plans (studies) both for all the towns areas: Kuřivody, Stráž pod Ralskem, Hamr na Jezeře, and Bělá pod Bezdězem, and for these selected sites: Bezděz, Boreček, Hamr, Hradčany, Hvězdov, Jablonec, Náhlov, Ploužnice, Svébořice, and Vrchbělá.

In 1997 the project presentation "The Conversion/Reuse of the former Ralsko MTA: Projects - Options - Chances" was elaborated both in Czech and English versions and presented at the NATO CCMS Pilot Study meetings. This presentation wishes to show both the natural and economic potential of the area assessed and its surroundings also, and offers several reusing projects and visions.

One of the latest planning contributions is the "Commercial Use of the former MTA Ralsko - Development Potential Assessment” prepared in 1998 by the State Institute of Land Development located in Brno for the Ministry of Regional Development. This study assessed 17 selected sites and 8 possible future uses (options) including SWOT analysis and main development preferences on the sites selected.

\section{Available and useable sources of financial assistance}

At the national (country) level there are some state programmes and funds providing special financial subsidies (grants) supporting or concerning conversion or reuse policies, from which the most useable in the Ralsko area seem to be: Countryside Reuse; State Contributions for Upgrading Rented Housing; Reconstruction of Block of Flats; Changing of Heating Systems; Renewable Sources in Energy Production and Consumption; Landscape and Nature Conservation; Rivers and Water in Landscape.

Moreover also some tax exemptions are to be implemented such as: incomes from environmentally sound industry and business; changing the heating 
systems to make them environmentally sound; environmentally sound construction and buildings.

A significant policy in the economic conversion and reuse might be the set of incentives to invest in the Czech Republic adopted by the Czech Government on 29 April 1998 containing grants to build technical infrastructure, grants to create new labor places and re-training, grounds sale for the lowest price, duty-free import of selected technology, etc.

At the international level there are also several options to apply for and use various sources and programmes of financial support to these needs, e.g. Phare CBC (Cross - Border Cooperation) Programme could be in particularly important, since the Ralsko area is part of the Euroregion Nisa along the EU (German) border and can use financial means from EU funds. Direct funding or investment by individual countries, companies, foundations, etc. is another available and optional way.

\section{Goals, expectations and visions}

- By 2000 year to accomplish privatization of the state property and to find new owners.

- To accelerate housing modernization and reconstruction and essentially to enhance the quality of housing and living.

- To increase the use of existing and new funds (grants) and all other forms of national and international financial support to develop appropriate reuse.

- To deal increasingly with finding (getting) convenient and reliable investors and enterpreneurs both in the country and abroad.

- The exchange of visits and contacts with similar areas and municipalities abroad (in particular in Poland, Hungary and Germany) might and should prove very important.

- To improve links and cooperation between local and central government. Following an adopted decision 14 new "self-governing counties" will be established in the year 2000 and the Ralsko area will be included in the new "Liberec county", and proper improvement is expected.

- To attempt to use extensive lands producing renewable energy sources as an example of modern energy production (consumption).

- To involve more and deal with domestic industry in the surroundings, in particular with Škoda Car Factory (located only $25 \mathrm{~km}$ away), which is presently the most successful Czech company.

- To focus on the labor force within the uranium industry (Diamo, st. co.), which is nearby and will be affected extensively by the ongoing closure.

- To deal more, essentially, with the development of tourism and sport in accordance with expected trends and demands, and preserve (respect) the really unique nature and landscape heritage.

\section{Projects, options, chances and priorities}

There are at present some projects, options and chances for economic and cultural reuse located in accordance with land-use planning, but they are mostly lacking sufficient technical and investment promotion.

As the most important and also the most demanding projects (chances), which have been already presented in the NATO CCMS Reuse Pilot Study, 


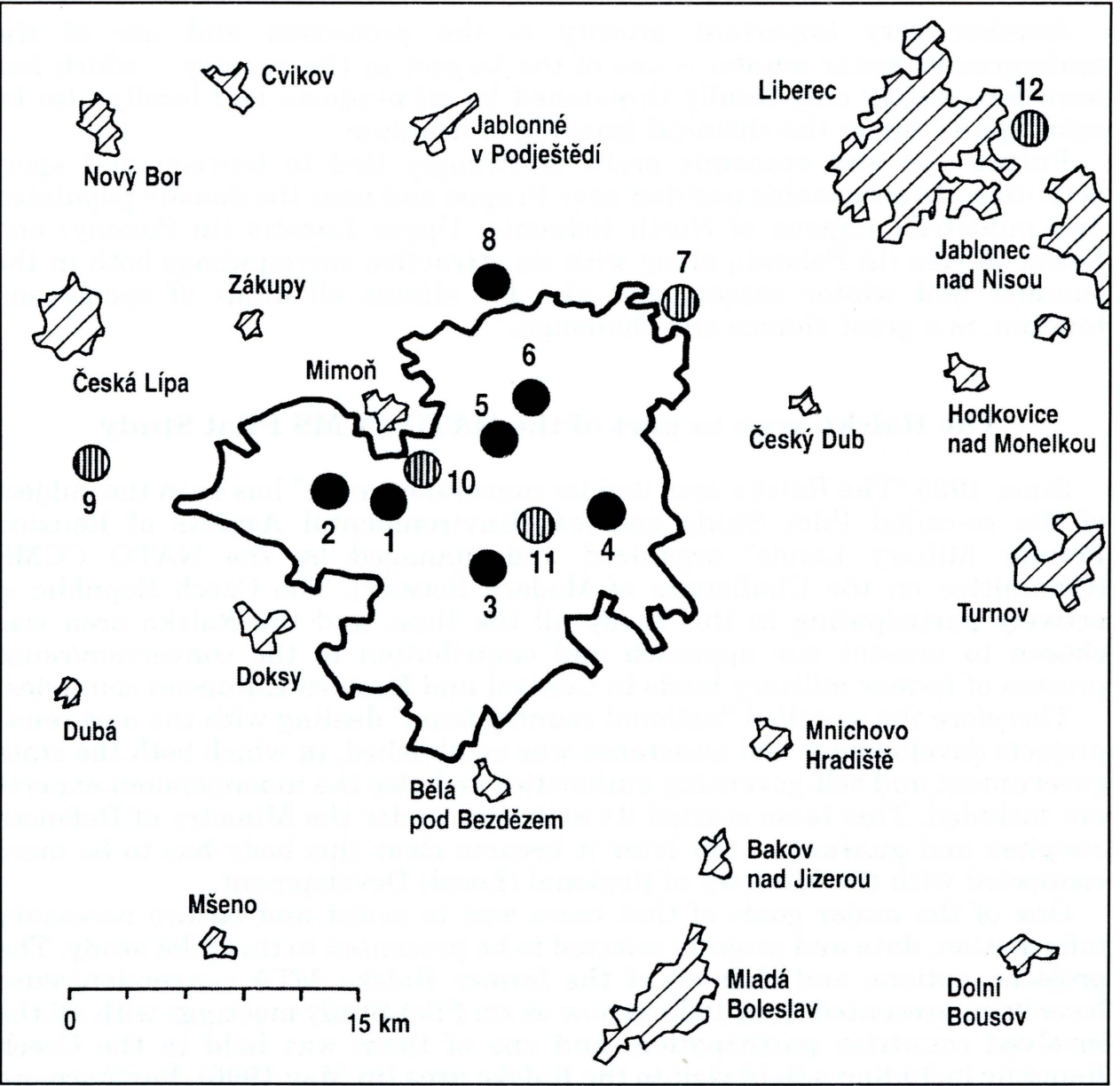

Fig. 7 - Conversion/reuse of the former military training area Ralsko (Czechia) - projects, options and chances for reuse. 1 - Hradčany Air Base, 2 - Hradčany Village, 3 - Kuřivody Center and Industrial Area, 4 - Jablonec Specific Leisure Center, 5 - Hvězdov Tourism Center, 6 - Svébořice Breeding Station, 7 - Lázně Kundratice Spa, 8 - Stráž pod Ralskem Uranium Mining Remediation, 9 - Novozámecký rybník Fishpond, 10 - Hradčany/Ploužnice Residential Area, 11 - Židlov Shooting Range - Domestic Animal Park.

are to be assigned: Air Base Reuse (Hradčany Base); Village Conversion (Hradčany Village); Historical Town Center Renewal (Kuřivody Town); An Industrial Area (Kuřivody Town); Specific Leisure Activities Center (Jablonec Base); Tourism and Sporting Center (Hvězdov Area); Spa Development (Kundratice Spa); Breeding Station for Endangered Animal Species (Svébořice Base).

One of the clear priorities is and has to be to the preservation of really unique - not only in the Czech, but in the European context as well - nature and landscape heritage. The Ministry of the Environment is going to declare two National Nature Reserves here - "Pristine Meanders of the Ploučnice River" and "Sandstones and Wetlands of Doksy" following a draft which originated in 1933 (at that time one of first considered sites in Czechoslovakia). 
Another very important priority is the protection and use of the underground water aquifer - one of the largest in the country - which has been fortunately only locally threatened by oil products and locally also by acid liquids due to the chemical leaching of uranium.

Future use and economic profit is strongly tied to tourism and sport activities. Its geographic position near Prague and near the densily populated and industrial regions of North Bohemia, Upper Lusatia (in Saxony) and Lower Silesia (in Poland), along with its attractive surroundings both in the summer and winter season, and also for almost all kinds of sports and tourism, is a great chance and challenge.

\section{The Ralsko area as part of the NATO CCMS Pilot Study}

Since 1995 "The Ralsko area and its conversion/reuse" has been the subject of the so-called Pilot Study entitled "Environmental Aspects of Reusing Former Miliary Lands" organized and managed by the NATO CCMS (Committee on the Challenges of Modern Society). The Czech Republic is actively participating in this study all the time, and the Ralsko area was chosen to present our approach and contribution to the conversion/reuse process of former military lands in Central and Eastern European countries.

Therefore the so called "national country team" dealing with the new reuse projects development and assistance was established, in which both the state government and self-governing authorities and also the indenpendent experts are included. This team started its activities under the Ministry of Defences auspices and guarantee, but later it became clear this body has to be more connected with the Ministry of Regional (Local) Development.

One of the major goals of that team was to assist and ensure necessary information, data and projects selected to be presented to this pilot study. The projects, options and chances of the former Ralsko MTA conversion/reuse have been presented from 1995 to now at six Pilot Study meetings with all the involved countries participation, and one of them was held in the Czech Republic including a field visit to the Ralsko area (in May 1996). Furthermore the Ralsko area and projects selected were presented also at two particular meetings to investors, developers and the financial community in Berlin and Washington in 1997. Along with us Poland, Lithuania, Latvia and Estonia prepared and presented conversion/reuse projects.

The last Pilot Study meeting was held in Warsaw in July 1998, and its main focus was both the presentation and discussion future use visions, and how to create a comprehensive structure and contents of the development visions.

\section{Recommendations}

Dealing with the problems of former miliary lands cannot be, and in no country which has succeeded in it is not either, only a municipality and region matter. These problems and challenges concern the whole country and have to be addressed by the whole country and by the Central Government at the highest level. Military lands and areas serve and served for the defence needs of the whole country and therefore the whole country has to face the responsibility for their conversion and reuse. 
The advanced and successful social and economic conversion of the Ralsko area is not manageable by the power of the region, in which the districts of Česká Lípa, Mladá Boleslav and Liberec are to be included, and which means about $4 \%$ out of the total area of the Czech Republic. This regions part in the whole country population and labor force is still less - only $3.6 \%$. However, the Ralsko area constitutes more than $60 \%$ of all the former military lands designated for new use in the country. Financial contributions from the state budget in order to ensure, maintain and reuse both state and other property as the material basis of reuse should therefore be adequate to this part and to the role of the Ralsko area.

The state administration should also actively and preferentially assist in getting, spreading, implementation and exchange of all new knowledge and experience related to the conversion/reuse process in other countries (this is also the opinion and one of the goals of the NATO CCMS Pilot Study). Particularly significant and encouraging are the results, which have been achieved during the same short period, on the territory of the former German Democratic Republic (at the town of Jueterbog, south of Berlin in the Brandenburg) and Poland (at Polands youngest town Borne Sulinowo north of Poznan near the Baltic Sea, a visit there being particularly recommendable).

\section{Conclusions}

Dealing with the problems of social and economic conversion/reuse within such a large and also depopulated area, with outstanding and unique natural values even from the international point of view, has to be logically divided into some different levels. In order to find ways to support and accelerate affordable conversion and reuse it is necessary to focus on the clearing of those different levels (responsibilities).

It is quite clear that to meet and solve these problems cannot be and will not be simple, short-term or cheap. Both local and regional authorities, both overregional, national and overnational bodies - with their different interests, needs and potential - have to face these new and so far mostly unknown challenges by necessary joint cooperation.

Information and experience achieved in other countries has to be increasingly obtained and used. In particular we should pay attention to the situation, progress and development made on the territories of Poland and the former GDR. We might not forget of course that also some kind of competition and rivalry plays and will play its role in that. Not only the contents and feasibility of our projects (offers), but also their quality and external forms and their presentation, and the extent and quality of all managerial activities connected with it both in the country and abroad, will increasingly decide the progress and success rate of the conversion/reuse process.

\section{References:}

BLAŽKOVÁ, J. (1997): Vznik vojenského újezdu Ralsko. In: Vlastivědný sborník Českolipska. Okresní vlastivědné muzeum Česká Lípa, pp. 9-46.

Bývalý vojenský výcvikový prostor Ralsko. Vlastivědný sborník Českolipska - Bezděz, 5 , Okresní vlastivědné muzeum Česká Lípa, p. 577.

HAMERSKY, A. (1995): Ralsko Region - Needs Assessment for Economic Development. U.S. Foundation for a Civil Society, without page numbers. 
Komerční využití bývalého vojenského prostoru Ralsko. Hodnocení rozvojového potenciálu. Ústav územního rozvoje, Brno 1998, without pages numbers.

Možnosti využití oblasti Ralsko pro potřeby cestovního ruchu. Mag Consulting, s. s r. o., Praha 1997, 43 p., encl.

POŠTOLKA, V. et al. (1996): Chovná stanice pro zvláště ohrožené druhy zvířat v bývalém vojenském výcvikovém prostoru Ralsko - Svébořice. Návrh projektu. In: NATO CCMS Pilot Study Meeting, London 1996, 12 p., encl.

POŠTOLKA, V. et al. (1997): Nové využití bývalého vojenského prostoru Ralsko: Projekty náměty - možnosti. In: NATO CCMS Pilot Study Meeting. Washington, Berlin, 40 p., encl.

Projekt Ralsko - Svobodná zóna Ralsko. Textová a přílohová část, 12 svazků, Sobodná zóna, a. s. Praha 1993.

Usnesení vlády ČR č. 398 ze dne 29. 4. 1998 k souboru investičních pobídek pro investory v České republice.

\section{Su m m a r y}

\section{CONVERSION AND REUSE OF THE FORMER MILITARY TRAINING AREA OF RALSKO}

The former military training area (further abbr. as MTA) of Ralsko (or formerly also Mimoň) was of $250 \mathrm{sqkm}$ and it was until recently the second largest MTA in the Czech Republic. It was established in 1950 and used by the Soviet Army from 1968 to 1991 . After the Soviet Army's withdrawal it was decided to discontinue its military use. Since the beginning of 1992 it has been the largest former MTA in the country in need of reuse and conversion.

The Ralsko area is first of all a unique area because of its natural heritage. Almost $90 \%$ of its total area has remained untouched - according to some experts - by direct human impact in the last 50 years. It is very rare in Central Europe to find such a large and continious area kept in substance in natural development. From this point of view the Ralsko area may be considered one of the most interesting and valuable areas in Central Europe. Ralsko is for these reasons one of two areas in the Czech Republic, which have been declared "biogenetic reserves" within the European network (EECONET).

One of the clear priorities is and has to be the preservation of the really unique - not only in a Czech, but in a European context - natural and landscape heritage. The Ministry of the Environment is going to declare two National Nature Reserves here - "Pristine Meanders of the Ploučnice River" and "Sandstones and Wetlands of Doksy" based on a draft which originated in 1933 (at that time one of the first considered sites in Czechoslovakia).

Another very important priority is the protection and use of the underground water aquifer - one of the largest in the country - which has been fortunately only locally threatened by oil products and locally also by acid liquids due to chemical leaching of uranium.

Future use and economic profit is strongly tied to tourism and sport activities. Its geographic position near Prague and near the densily populated and industrial regions of North Bohemia, Upper Lusatia (in Saxony) and Lower Silesia (in Poland), along with its attractive surroundings both in the summer and winter seasons, and also for almost all kinds of sports and tourism, is a great chance and challenge.

Since 1995 "The Ralsko area and its conversion/reuse" has been the subject of the socalled pilot study entitled "Environmental Aspects of Reusing Former Miliary Lands" organized and managed by the NATO CCMS (Committee on the Challenges of Modern Society). The Czech Republic is actively participating all the time in this study, and the Ralsko area was chosen to present our approach and contribution to the conversion/reuse process of former military lands in Central and Eastern European countries.

There are at present some projects, options and chances for economic and cultural reuse located in accordance with land-use planning, but they are mostly lacking sufficient technical and investment promotion.

As the most important and also the most demanding projects/chances, which have been already presented in the NATO CCMS Reuse Pilot Study, are to be assigned: Air Base Reuse (Hradčany Base); Village Conversion (Hradčany Village); Historical Town Center Renewal (Kuřivody Town); An Industrial Area (Kuřivody Town); Specific Leisure Activities 
Center (Jablonec Base); Tourism and Sporting Center (Hvězdov Area); Spa Development (Kundratice Spa); Breeding Station for Endangered Animal Species (Svébořice Base).

The state administration should also actively and preferentially assist in the getting, spreading, implementation and exchange of all new knowledge and experience related to the conversion/reuse process in other countries (this is also the opinion and one of the goals of the NATO CCMS Pilot Study). Particularly significant and encouraging are the results, which have been achieved in the same short period, on the territory of the former German Democratic Republic (at. the town of Jueterbog, south of Berlin in the Brandenburg) and Poland (at Poland's youngest town Borne Sulinowo north of Poznan nearby Baltic Sea, a visit there being particularly recommendable).

(The author is with the Department of Geography, Faculty of Education, Technical University, Hálkova 6, 46117 Liberec.)

Arrived at the editors office on June 20, 1998

Recommended for publication by Bohumír Janský and Zbyněk Ryšlavý 